\title{
Polyporus admirabilis (Polyporaceae), new to Europe
}

\author{
MARIA NUÑEZ
}

\begin{abstract}
NUÑEZ, M. 1994: Polyporus admirabilis (Polyporaceae), new to Europe. - Karstenia 34: 1-3. ISSN 0453-3402

Polyporus admirabilis Peck, a North American species, has recently been found in Norway. The species is described, and the differences between it and other, similar species are discussed. $P$. admirabilis resembles large specimens of $P$. varius, but spores are smaller and the microstructure of the pilear surface is different. The Norwegian finds derive from trunks of living Quercus petraea and Malus domestica.
\end{abstract}

Key words: Aphyllophorales, Europe, Polyporus

Maria Nuñez, Department of Botany, Division of Biology, University of Oslo, Blindern P.O. Box 1045, N-0316 Oslo 3, Norway; present address: Avda. Betanzos 13, 2.3., 28029 Madrid, Spain

\section{Introduction}

Polyporus Fr. is a cosmopolitan genus with 16 species recorded for Europe (Nuñez \& Ryvarden, in prep.). $P$. admirabilis was first described from Maine, USA, growing on Malus (Peck 1899). Basidiocarps formed imbricate tufts more than 30 $\mathrm{cm}$ in diameter, while individual pilei were 10-15 $\mathrm{cm}$ broad, with a white, pale yellow or cream upper surface. Dodge (1916) reported the presence of solitary basidiocarps of $P$. admirabilis causing heart-rot on the same living host. Moreover, he placed $P$. underwoodii Murrill, growing on Carya, Fraxinus and Salix, as a synonym of $P$. admirabilis, noting that the pilei, initially white, became discoloured and leathery with age. The synonymy of $P$. underwoodii with $P$. admirabilis has been confirmed by Overholts (1953) and Ryvarden (1985).

Gilbertson and Martin (1976) described $P$. coronadensis as a large, imbricate species with single pilei $10-34 \mathrm{~cm}$ wide, cream-coloured, darkening to pale brown and mottled with dark brown to black spots. The species, growing on living Quercus hypoleucoides, was said to be similar to $P$. admirabilis except for its huge imbricate pilei up to $46 \mathrm{~cm}$ across and the darker colour of the pilei.

Burdsall and Lombard (1989) described $P$. lowei as a species with imbricate basidiocarps growing on dead Acer saccharum. The species was said to differ from $P$. coronadensis in its host, and in microscopical characters such as width of vegetative hyphae and the presence of gloeopherous hyphae in young specimens.

In the mild January of 1993, a solitary polypore found on living Quercus petraea at Asker, Norway, was brought to the Department of Botany of the University of Oslo for identification. After macroand microscopical studies, it was identified as $P$. admirabilis. Later on, an imbricate specimen of the same species collected on Malus was discovered in herb. $\mathrm{O}$, where it had been labelled as $P$. varius $\mathrm{Fr}$.

These two specimens constitute the first records of $P$. admirabilis in Europe. 


\section{Material and methods}

The specimens examined are listed under the species description.

Basidiocarp tissues were torn apart under a WILD M3B dissecting microscope with the help of a needle and a razor blade. They were mounted in $5 \% \mathrm{KOH}$ and observed at $\mathrm{x} 400$ and $\times 1000$ magnifications with a Zeiss microscope provided with phase contrast. Measurements were made in $5 \% \mathrm{KOH}$.

Macro- and microanatomical terms have been taken from Snell and Dick (1971). Skeleto-binding cells are as defined by Corner (1981), but they are called here skeletobinding hyphae.

Herbarium abbreviations are taken from Holmgren et al. (1981).

\section{Polyporus admirabilis Peck}

Bull. Torrey Bot. Club 26: 69. 1899.

Polyporus underwoodii Murrill in Peck, New York State Mus. Bull. 105: 27. 1906.

Polyporus coronadensis Gilb. \& K.J. Martin, Mycologia 68: 1117. 1976.

Polyporus lowei Burds. \& Lombard, Mem. New York Bot. Garden 49: 147. 1989, non P. lowei (Pilát) J. Lowe, New York State Coll. For. Tech. Publ. 60: 78. 1942.

Basidiocarps. Annual, laterally stipitate or substipitate, solitary or imbricate. Single pilei infundibuliform to dimidiate, $6-43 \mathrm{~cm}$ wide, up to $4.5 \mathrm{~cm}$ thick, upper surface white when fresh, ochraceous in different tones when dry and old, glabrous and pelliculose, smooth to radially striate, sometimes mottled with dark spots. Pore surface white, drying ochraceous, tubes brittle when dry. Pores angular, 4-5 per mm, enlarging at maturity, decurrent on the stipe. Context white to cream, firm, up to $4 \mathrm{~cm}$ thick. Stipe up to $8 \mathrm{~cm}$ long and $3.5 \mathrm{~cm}$ thick, usually poorly developed, concolorous with the pileus and darkening to black at the base, glabrous to finely tomentose.

Hyphal system. Dimitic. Generative hyphae clamped, 2.5-4 $\mu \mathrm{m}$ wide, forming a cutis on the stipe and on the pilear surface. Gloeopherous hyphae present in the context of young specimens. Skeleto-binding hyphae hyaline, solid, 3-7(-10) $\mu \mathrm{m}$ in diam.

Basidia. Clavate, 4-sterigmate, 22-35 × 5-8 $\mu \mathrm{m}$.

Basidiospores. Cylindrical, 6.5-7-9 × 2.5-3.5 $\mu \mathrm{m}$.

Cultural characters. See Burdsall and Lombard (1989 as P. loweii).

Substrata. In Europe, on living wood of Malus domestica and Quercus petraea. In North America, on dead and living wood of Acer, Betula, Carya, Fraxinus, Juglans, Malus, Pyrus, Quercus, Salix, causing white rot.
Distribution. North America and Europe (Norway).

\section{Specimens examined}

Norway. Akers hus: Asker, Nesøya, on living Quercus petraea, I.1993 Jọrgensen (O). Buskerud: Ringerike, Klekken, on living Malus, X.1960 Eftestol (O).

USA. Arizona: Turkey Creek, Chiricahua Mts., Coronado Nat. Forest, Cochise County, on living Quercus hypoleucoides, VIII.1971, type of P. coronadensis AZ010680, Martin (ARIZ). Maine: Riverside, on wood of apple trees, VIII. and IX.1898, type of P. admirabilis, Burt (NYS). Maryland: as P. pennsylvanicus, BPI 11311 (O).

\section{Discussion}

$P$. admirabilis is recognized by its large and thick, creamy, laterally stipitate basidiocarps and medium-size spores $(6.5-9 \times 2.5-3.5 \mu \mathrm{m})$. Large specimens of $P$. varius Fr. (= P. leptocephalus (Jacq.:Fr.) Fr.) can be distinguished by their larger spore size $(8.5-12 \times 2.5-4 \mu \mathrm{m})$ and the presence of a palisade rather than a cutis in the pilear surface.

An examination of type materials of both species leads me to consider P. coronadensis a synonym of $P$. admirabilis. Except for its imbricate basidiocarps and the lack of gloeopherous hyphae, $P$. coronadensis coincides both macro- and microscopically with the $P$. admirabilis specimen found at Asker (coll. Britt Jørgensen).

$P$. lowei Burds. \& Lombard is a later homonym of $P$. lowei (Pilát) J. Lowe (= Oligoporus lowei (Pilát) Gilb. \& Ryvarden). The description given by Burdsall and Lombard (1989) coincides with that of P. admirabilis. The differences in hyphal width are not considered here as taxonomically significant at species level and, as already noted, gloeopherous hyphae were also found in the specimen from Asker.

P. chozeniae (Vassilkov) Parmasto has larger spores $(10.55-11.70 \times 4.31-4.38 \mu \mathrm{m}$, Parmasto 1975). According to the description, this taxon would seem to be a large specimen of $P$. varius.

The description of $\mathrm{P}$. subadmirabilis Bondartsev, found at Slavjansk, Primorsk province (Russian Far East), implies P. admirabilis, although the author emphasizes some differences (Bondartsev 1962). I was unable to borrow the type from LE to verify its status.

Piptoporus quercinus (Fr.) Pilát, growing on living Quercus, could be mistaken macroscopically for $P$. admirabilis. There is no difference as to spore size. However, $P$. quercinus is trimitic with skeletal hyphae (Ryvarden 1978) and causes a brown rot. 
Acknowledgements. Britt Jørgensen is thanked for placing her specimen at my disposal; Gro Gulden for arranging loans from $\mathrm{O}$; and Jens Petersen and Leif Ryvarden for interesting discussion concerning the species.

\section{References}

Bondartsev, A.S. 1962: Polypori novi ex Oriente extremo. - Not. Syst. Sect. Crypt. Inst. Bot. Nom. V.L. Komarovii Acad. Sci. URSS 15:103-111.

Burdsall, H.H. \& Lombard, F.F. 1989: Polyporus lowei, a new species from the Great Lakes region. - Mem. N.Y. Bot. Garden 49:147-151.

Corner, E.J.H. 1981: The agaric genera Lentinus, Panus and Pleurotus, with particular reference to Malaysian species. - Beih. Nova Hedwigia 78:1-169.

Dodge, B.O. 1916: Fungi producing heart-rot of apple trees. - Mycologia 8:5-15.

Gilbertson, R.L. \& Martin, K.J. 1976: Polyporus coronadensis, a new species from Arizona. Mycologia 68:1116-1120.

Gilbertson, R.L. \& Ryvarden, L. 1987: North American Polypores 2. - Pp. 437-885. Fungiflora, Oslo.
Holmgren, P.K., Keuken, W. \& Schofield, E.K. 1981: Index herbariorum 1. The herbaria of the world. Regnum Vegetabile 106:1-452.

Overholts, L.O. 1953: The Polyporaceae of the United States, Alaska, and Canada. - 446 pp. Univ. Michigan Press, Ann Arbor.

Parmasto, E. 1975: On Polyporus chozeniae (Vassilk.) Parm. comb. nov. and related species. - Folia Crypt. Estonica 5:35-38.

Peck, C.H. 1899: New species of fungi. - Bull. Torrey Bot. Club 26:69-71.

Ryvarden, L. 1978: The Polyporaceae of North Europe 2. Inonotus to Tyromyces. - Pp. 215-507. Fungiflora, Oslo.

Ryvarden, L. 1985: Type studies in the Polyporaceae 17. Species described by W.A. Murrill. - Mycotaxon 23:169-198.

Snell, W.H. \& Dick, E.A. 1971: A glossary of mycology. $181 \mathrm{pp}$. Harvard University Press, Cambridge.

Received on 12 July 1993 